\title{
Estimation of the faeces output of grazing animals from the concentration of chromium sesquioxide in a sample of faeces
}

\author{
1. Comparison of estimates from samples taken at fixed times \\ of day with faeces outputs measured directly
}

By J. P. LANGLANDS,* J. L. CORBETT,* I. McDONALD AND G. W. REID Rowett Research Institute, Bucksburn, Aberdeen

\section{(Received 3 August 1962)}

Estimation of the mean daily concentration of chromium sesquioxide $\left(\mathrm{Cr}_{2} \mathrm{O}_{3}\right)$ in the faeces of ruminant animals is frequently attempted by analysis of small samples taken manually from the rectum at one or two fixed times of day. Kane, Jacobson 8 Moore (1952) studied the diurnal pattern of $\mathrm{Cr}_{2} \mathrm{O}_{3}$ excretion by stalled cows and suggested that rectal, or 'grab', samples taken during the periods $04.00-06.00 \mathrm{~h}$ and I3.00-I 5.00 h would, when combined, yield a value for $\mathrm{Cr}_{2} \mathrm{O}_{3}$ concentration similar to the $24 \mathrm{~h}$ mean. A similar system has been used for grazing cattle by Lancaster, Coup \& Percival (1953), Smith \& Reid (1955) and many other workers. The validity of the technique has been criticized on the grounds that the diurnal pattern of $\mathrm{Cr}_{2} \mathrm{O}_{3}$ excretion is not stable and varies with any change in the pattern of feeding behaviour (Raymond \& Minson, I955). Many workers consider that the possible errors and biases are so large as to be unacceptable, which is unfortunate as grab sampling is very easy to carry out and involves no difficulties in obtaining separate samples for individual animals. However, the validity of the method has been studied only when $\mathrm{Cr}_{2} \mathrm{O}_{3}$ has been given as a quick-release dose, usually as gelatin capsules containing the marker in a finely divided form. It was thought that better results might be obtained with the dose in a form that would be retained for a longer time in the reticulo-rumen and give a sustained release of $\mathrm{Cr}_{2} \mathrm{O}_{3}$ leading to more even mixing with digesta. Balch, Reid \& Stroud (I957) suggested that $\mathrm{Cr}_{2} \mathrm{O}_{3}$ macaroni (Edin, Kihlén \& Nordfeldt, I944-5) should be used, but we found (unpublished observations) that the line describing changes with time in the concentration of $\mathrm{Cr}_{2} \mathrm{O}_{3}$ in digesta flowing through the duodenum of a sheep after administration of a single dose of the macaroni was intermediate between those presenting the result from the administration of $\mathrm{Cr}_{2} \mathrm{O}_{3}$ incorporated in a specially prepared paper or in a capsule. Such a line gives an indication of the rate of clearance of $\mathrm{Cr}_{2} \mathrm{O}_{3}$ from the reticulorumen (Corbett, Greenhalgh \& McDonald, 1958). Results of a subsequent trial (Langlands, 1962 ) in which sheep received $\mathrm{Cr}_{2} \mathrm{O}_{3}$ macaroni or the paper regularly and in standard amounts were consistent with these observations in that variability in the faecal concentration of $\mathrm{Cr}_{2} \mathrm{O}_{3}$ tended to be greater when the macaroni rather than the paper was administered.

* Present address: CSIRO Division of Animal Physiology, Armidale, NSW, Australia. 
Since dosing with paper gave a low variability in $\mathrm{Cr}_{2} \mathrm{O}_{3}$ concentration in the faeces of hand-fed sheep (Corbett, Greenhalgh, McDonald \& Florence, I960) this type of dose was compared in field trials with $\mathrm{Cr}_{2} \mathrm{O}_{3}$ capsules to determine whether the reliability of the grab-sampling procedure with grazing animals is increased when the paper is used.

EXPERIMENTAL

\section{Management of animals}

In each trial six steers or six wether sheep grazed continuously one area of pasture. Three animals were dosed with $\mathrm{Cr}_{2} \mathrm{O}_{3}$ capsules and three with $\mathrm{Cr}_{2} \mathrm{O}_{3}$ paper. The six steers were given a total of $40 \mathrm{lb}$ hay daily at $17.00 \mathrm{~h}$ to supplement the sparse late-autumn grazing.

All animals wore harness and faeces-collection bags to which they had been accustomed.

\section{Dosing with $\mathrm{Cr}_{2} \mathrm{O}_{3}$}

Gelatin capsules containing, for sheep and cattle respectively, $0.96 \pm 0.01$ or $9.83 \pm$ $0.04 \mathrm{~g} \mathrm{Cr}_{2} \mathrm{O}_{3}$ in suspension in oil were obtained from R. P. Scherer and Co. Ltd, Slough, Bucks. Doses of $\mathrm{Cr}_{2} \mathrm{O}_{3}$ paper, each rolled up in a sheet of thin quarto paper for administration, contained $0.94 \pm 0.01$ or $6.20 \pm 0.08 \mathrm{~g} \mathrm{Cr}_{2} \mathrm{O}_{3}$ for sheep and cattle respectively, the largest quantities that could readily be administered at one time by balling gun. The paper was part of a large batch made to our specifications by C. Davidson and Sons Ltd, Bucksburn, Aberdeen. It contained approximately $33 \%$ $\mathrm{Cr}_{2} \mathrm{O}_{3}$ in the dry matter and was in the form of strips about $3 \times 13^{\circ} \mathrm{mm}$ which were thoroughly mixed and allowed to reach moisture equilibrium before the doses were weighed out.

\section{Trials}

Three trials were made; in trial I the steers were dosed twice daily at 09.00 and $\mathrm{I} 6.30 \mathrm{~h}$, in trial 2 the sheep were dosed twice daily at 08.00 and $\mathrm{I} 6.00 \mathrm{~h}$ and in trial 3 the sheep were dosed once daily at $08.00 \mathrm{~h}$.

Trial I (steers). Grab sampling was begun at $09.00 \mathrm{~h}$ on the I Ith day of marker administration and the animals wore faeces collection bags from this time. Twice daily at dosing times for 18 consecutive days the bags were changed and the weight of fresh faeces was determined. After thorough mixing, one-tenth portions were combined for each animal over 3-day periods. A $300 \mathrm{~g}$ grab sample of faeces was taken from each animal at each dosing time and these samples also were combined over 3-day periods. On the few occasions when the rectum was empty the grab sample consisted of $300 \mathrm{~g}$ faeces taken from the top of the faeces in the collection bag.

Trials 2 and 3 (sheep). From $08.00 \mathrm{~h}$ on the $\mathrm{I} \mathrm{Ith}$ day of marker administration the sheep wore collection bags which were emptied at 08.00 and at $\mathrm{I} 6.00 \mathrm{~h}$ for $\mathrm{I} 5$ and I 8 consecutive days in trials 2 and 3 respectively. It was found that faeces were not always readily obtained from the rectum of the sheep. Instead, $30 \mathrm{~g}$ quantities of faeces, equivalent to grab samples, were obtained from the bags approximately $40 \mathrm{~min}$ 
after the main collections had been emptied out in the morning and evening of each day. In both trials the main collections from each sheep were combined over 3-day periods. Grab samples were also combined over 3 -day periods; in trial 3 only, the morning and evening samples were separately combined.

\section{Determination of $\mathrm{Cr}_{2} \mathrm{O}_{3}$ in faeces}

The concentration of $\mathrm{Cr}_{2} \mathrm{O}_{3}$ in the organic matter of the faeces samples was determined by a modification (Commonwealth Bureau of Pastures and Field Crops, 196r) of the method of Christian \& Coup (1954).

\section{Statistical analysis}

The error of an estimate of the quantity of faeces excreted in a given period, calculated from the concentration of $\mathrm{Cr}_{2} \mathrm{O}_{3}$ in the fraction analysed, may be considered to have two main components. These are a long-term component resulting from the failure of marker output to equal marker intake over the period of estimation and a short-term component associated with the sampling procedure. The following nomenclature will be used in describing the errors.

$D$ The quantity of $\mathrm{Cr}_{2} \mathrm{O}_{3}$ administered during the period over which total faeces output is to be estimated.

$F \quad$ The quantity of faeces organic matter excreted during the period. In these trials $F$ was determined from the weight of faeces collected in bags plus the weight of grab samples.

$C_{R}$ The concentration of $\mathrm{Cr}_{2} \mathrm{O}_{3}$ in the organic matter of a representative sample of the faeces collected in bags.

$C_{G}$ The concentration of $\mathrm{Cr}_{2} \mathrm{O}_{3}$ in the organic matter of the grab samples of faeces combined over the period of estimation. In trial 3 , morning and evening grab samples were separately combined and analysed and yielded the values $C_{G M}$ and $C_{G E}$ respectively; their arithmetic mean is approximately equivalent to the term $C_{G}$ in trials $\mathrm{I}$ and 2.

The estimate of faeces output calculated from the concentration of $\mathrm{Cr}_{2} \mathrm{O}_{3}$ in the combined grab sample is $D / C_{G}$. The error in the estimate is $\left(F-D / C_{G}\right)$, which equals the sum of the long-term error $\left(F-D / C_{R}\right)$ and the short-term error $\left(D / C_{R}-D / C_{G}\right)$.

\section{RESULTS}

In all three trials estimates of the long-term, short-term and total errors were obtained for each animal in each 3 -day period. The mean values and standard deviations of these estimates are given for each animal in Table I (long-term errors), Table 2 (short-term errors) and Table 3 (total errors). In each instance the mean value estimates the bias, or constant part of the error, whereas the standard deviation estimates the random component of the error. To facilitate comparisons between different trials and animals, the means and standard deviations for each animal have been standardized by expressing them as percentages of the mean 3-day faecal output $(F)$ for that animal. 


\section{Biases}

The mean values of $\left(F-D / C_{R}\right)$ in Table I are almost all negative, significantly so for two animals in trial $\mathrm{I}$ and two in trial 3 , indicating that recovery of $\mathrm{Cr}_{2} \mathrm{O}_{3}$ was incomplete. The mean loss for all the animals was about $3 \%$ and probably arose from failure to collect all the faeces.

Table I. Long-term errors. Means and standard deviations of differences $\left(F-D / C_{R}\right)$ between direct measurements of faecal output $(F)$ by grazing animals over 3-day periods and estimates from $\mathrm{Cr}_{2} \mathrm{O}_{3}$ concentration in representative samples of faeces $\left(D / C_{R}\right)$, all expressed as percentages of $(F)$

\begin{tabular}{|c|c|c|c|c|}
\hline $\begin{array}{c}\text { Type of } \\
\mathrm{Cr}_{2} \mathrm{O}_{3} \text { dose }\end{array}$ & $\begin{array}{c}\text { Animal } \\
\text { no. }\end{array}$ & $\begin{array}{l}\text { Trial I } \\
\text { (steers) }\end{array}$ & $\begin{array}{l}\text { Trial } 2 \\
\text { (sheep) }\end{array}$ & $\begin{array}{l}\text { Trial } 3 \\
\text { (sheep) }\end{array}$ \\
\hline \multicolumn{5}{|c|}{ Means } \\
\hline \multirow[t]{4}{*}{ Capsules } & 1 & $-6 \cdot 5^{* *}$ & $-4 \cdot 4$ & $-8 \cdot 8 * * *$ \\
\hline & 2 & $-7 \cdot 8 \dagger$ & $+12 \cdot 3$ & $-1 \cdot 7$ \\
\hline & 3 & $-2 \cdot 4$ & $-I \cdot 9$ & - I $5 \cdot 9^{*}$ \\
\hline & Mean & $-5 \cdot 6$ & $+2 \cdot 0$ & $-8 \cdot 8$ \\
\hline \multirow[t]{4}{*}{ Paper } & 4 & $-5 \cdot 5$ & $-I \cdot I$ & -0.2 \\
\hline & 5 & $-8 \cdot 2^{* *}$ & $-2 \cdot 0$ & -0.1 \\
\hline & 6 & $-4 \cdot 6$ & $-3 \cdot 2$ & $+I \cdot 2$ \\
\hline & Mean & $-6 \cdot I$ & $-2 \cdot I$ & +0.3 \\
\hline \multicolumn{5}{|c|}{ Standard deviations } \\
\hline \multirow[t]{4}{*}{ Capsules } & I & $\pm 2 \cdot 5$ & $\pm 13 \cdot 9$ & $\pm 2 \cdot 6$ \\
\hline & 2 & \pm 9.3 & \pm 14.7 & \pm 2.9 \\
\hline & 3 & \pm 50 & \pm 4.6 & $\pm I_{5} .1$ \\
\hline & Mean & $\pm 6 \cdot 3$ & $\pm 12 \cdot 0$ & $\pm 9 \cdot 0$ \\
\hline \multirow[t]{4}{*}{ Paper } & 4 & $\pm 7 \cdot 0$ & $\pm 4 \cdot 7$ & $\pm 8 \cdot 9$ \\
\hline & 5 & \pm 4.7 & \pm 100 & \pm 3.5 \\
\hline & 6 & \pm 100 & \pm 4.5 & \pm 7.4 \\
\hline & Mean & $\pm 7 \cdot 6$ & $\pm 6 \cdot 9$ & $\pm 7 \cdot 0$ \\
\hline
\end{tabular}

For details of dosing with $\mathrm{Cr}_{2} \mathrm{O}_{3}$ see p. 212 .

$+P<0.1 . \quad * P<0.05 . \quad * * P<0.01 . \quad * * * P<0.001$.

The mean values of $\left(D / C_{R}-D / C_{G}\right)$ in Table 2 must be considered separately for each trial. They show that there was some tendency for $D / C_{G}$ to be an underestimate of $D / C_{R}$ in trial $\mathrm{r}$, especially for the animals given paper, so that, in relation to $D / C_{R}$, $D / C_{Q}$ would tend slightly to underestimate faecal output under the conditions of that trial. In trial 2 this feature was found in the results for two of the animals receiving paper, but the values of $D / C_{G}$ for the animals receiving capsules showed a large bias in the opposite direction, which would have led to faecal outputs being overestimated, on average, by about $20 \%$. In trial 3, there were even larger errors when morning and evening grab samples were considered separately, and biases of the order of $10 \%$ when the morning and evening grab-sample concentrations were averaged.

The mean values of $\left(F-D / C_{G}\right)$ in Table 3 are largely dependent on those of $\left(D / C_{R}-D / C_{G}\right)$, and follow a similar pattern. 


\section{Random errors}

The results for the steers in trial I appeared to be less variable than those for sheep in trials 2 and 3 . In trial 2 the variability appeared to be less for animals given paper than for those given capsules, but it was not so in trials I or 3 , except for the morning samples in the latter.

Table 2. Short-term errors. Means and standard deviations of differences $\left(D / C_{R}-D / C_{G}\right)$ between estimates of faecal output $(F)$ by grazing animals over 3-day periods from $\mathrm{Cr}_{2} \mathrm{O}_{3}$ concentrations in representative samples $\left(D / C_{R}\right)$ and in corresponding bulked grab samples $\left(D / C_{G}\right)$, all expressed as percentages of $(F)$

\begin{tabular}{|c|c|c|c|c|c|c|}
\hline \multirow[b]{2}{*}{$\begin{array}{c}\text { Type of } \\
\mathrm{Cr}_{2} \mathrm{O}_{3} \text { dose }\end{array}$} & \multirow[b]{2}{*}{$\begin{array}{l}\text { Animal } \\
\text { no. }\end{array}$} & \multirow[b]{2}{*}{$\begin{array}{l}\text { Trial I } \\
\text { (steers) }\end{array}$} & \multirow[b]{2}{*}{$\begin{array}{l}\text { Trial } 2 \\
\text { (sheep) }\end{array}$} & \multicolumn{3}{|c|}{ Trial 3 (sheep) } \\
\hline & & & & $\begin{array}{c}\text { Grab } \\
\text { samples } \\
(M) \dagger\end{array}$ & $\begin{array}{c}\text { Grab } \\
\text { samples } \\
(E) \dagger\end{array}$ & $\begin{array}{l}\text { Combined } \\
\text { grab samples } \\
(M+E)\end{array}$ \\
\hline \multirow{3}{*}{ Capsules } & & & Means & & & \\
\hline & $\begin{array}{l}\mathbf{1} \\
2 \\
3\end{array}$ & $\begin{array}{l}+3.1 \\
-0.2 \\
-0.5\end{array}$ & $\begin{array}{l}-11 \cdot 4 \ddagger \\
-23 \cdot 2^{*} \\
-22 \cdot 8^{*}\end{array}$ & $\begin{array}{l}-4 \mathrm{I} \cdot 3^{* *} \\
-56 \cdot 3^{* * *} \\
-74 \cdot \mathrm{I}^{* * *}\end{array}$ & $\begin{array}{l}+27 \cdot 1^{*} \\
+36 \cdot 2 * * * \\
+46 \cdot 3^{* * * *}\end{array}$ & $\begin{array}{l}+5.0 \\
+9.5^{*} \\
+12.6^{* *}\end{array}$ \\
\hline & Mean & +0.8 & $-19 \cdot x$ & $-57 \cdot 2$ & $+36 \cdot 5$ & +9.0 \\
\hline \multirow[t]{2}{*}{ Paper } & $\begin{array}{l}4 \\
5 \\
6\end{array}$ & $\begin{array}{l}+4.4 \ddagger \\
+6 \cdot 6^{*} \\
+4.0^{*}\end{array}$ & $\begin{array}{l}+6 \cdot 2^{* * *} \\
-0.9 \\
+3 \cdot 6\end{array}$ & $\begin{array}{r}-3.9 \\
+13.5^{*} \\
+5.9^{*}\end{array}$ & $\begin{array}{l}-57.8 \ddagger \\
-29.0 \\
-29.9^{*}\end{array}$ & $\begin{array}{r}-22 \cdot 7 \\
-3 \cdot 3 \\
-8 \cdot 8\end{array}$ \\
\hline & Mean & $+5 \cdot 0$ & +3.0 & $+5 \cdot 2$ & $-38 \cdot 9$ & $-11 \cdot 6$ \\
\hline \multicolumn{7}{|c|}{ Standard deviations } \\
\hline Capsules & $\begin{array}{l}1 \\
2 \\
3\end{array}$ & $\begin{array}{l} \pm 4.5 \\
\pm 2.3 \\
\pm 6.4\end{array}$ & $\begin{array}{l} \pm 11.9 \\
\pm 13.4 \\
\pm 13.8\end{array}$ & $\begin{array}{l} \pm r 5 \cdot 0 \\
\pm 16 \cdot 3 \\
\pm 19 \cdot 3\end{array}$ & $\begin{array}{r} \pm 23 \cdot 6 \\
\pm 6 \cdot 7 \\
\pm 16 \cdot 0\end{array}$ & $\begin{array}{r} \pm 21 \cdot 0 \\
\pm 6 \cdot 0 \\
\pm 7 \cdot 6\end{array}$ \\
\hline & Mean & $\pm 4 \cdot 7$ & $\pm 13 \cdot 1$ & $\pm 17 \cdot 0$ & $\pm 16 \cdot 9$ & \pm 13.3 \\
\hline Paper & $\begin{array}{l}4 \\
5 \\
6\end{array}$ & $\begin{array}{l} \pm 4 \cdot 4 \\
\pm 6 \cdot 0 \\
\pm 4 \cdot 1\end{array}$ & $\begin{array}{l} \pm x \cdot 9 \\
\pm 4.7 \\
\pm 4.6\end{array}$ & $\begin{array}{r} \pm 14.7 \\
\pm 8.3 \\
\pm 3.2\end{array}$ & $\begin{array}{l} \pm 56 \cdot 4 \\
\pm 26 \cdot 7 \\
\pm 20 \cdot 9\end{array}$ & $\begin{array}{r} \pm 26.3 \\
\pm 3.3 \\
\pm 9.5\end{array}$ \\
\hline & Mean & $\pm 4 \cdot 9$ & $\pm 4 \cdot 0$ & $\pm 9 \cdot 9$ & $\pm 40 \cdot 0$ & $\pm 16 \cdot 3$ \\
\hline
\end{tabular}

For details of dosing with $\mathrm{Cr}_{2} \mathrm{O}_{3}$ see p. $2 \mathrm{I} 2$.

$\dagger M$, grab samples taken in the morning; $E$, grab samples taken in the evening.

$\ddagger P<0.1$. * $P<0.05$. ** $P<0.01$. *** $P<0.001$.

The values of $\left(F-D / C_{R}\right)$ were examined to determine whether the errors were correlated from one 3-day period to the next. No evidence was found of such correlation, the results appearing to be consistent with the hypothesis that the standard deviation $\left(S_{n}\right)$ of measurements over periods of $n$ days, where $n$ is greater than 3 , can be estimated from the standard deviation between 3 -day periods $\left(S_{3}\right)$ by the calculation $S_{n}=\sqrt{ }\left[3 S_{3}^{2} / n\right]$, applicable where observations are independent.

\section{DISCUSSION}

The standard deviations of the differences $\left(F-D / C_{G}\right)$ given in Table 3 for the cattle (trial I) receiving capsules are of the same order as the values of $\pm 5,10,5$ and $7 \%$ reported respectively by Coup (1950), Lancaster et al. (1953), Smith \& Reid (1955) 
and Coup \& Carter (quoted by Wallace, 1956), though their results were for longer collection periods. The mean value for the sheep receiving capsules in trial $2, \pm 13 \cdot 2 \%$, was similar to the value of $\pm 10-12 \%$ suggested by Lambourne (1957) but a little higher than the value of $\pm 9 \%$ given by Coop \& Hill (1962). In trial 3 the principal interest lies in the precision with which faeces output can be estimated from the

Table 3. Total errors. Means and standard deviations of differences $\left(F-D / C_{G}\right)$ between direct measurements of faecal output $(F)$ by grazing animals over 3-day periods and corresponding estimates from $\mathrm{Cr}_{2} \mathrm{O}_{3}$ concentration in bulked grab samples of faeces $\left(D / C_{G}\right)$, all expressed as percentages of $(F)$

\begin{tabular}{|c|c|c|c|c|c|c|}
\hline \multirow[b]{2}{*}{$\begin{array}{c}\text { Type of } \\
\mathrm{Cr}_{2} \mathrm{O}_{8} \text { dose }\end{array}$} & \multirow[b]{2}{*}{$\begin{array}{c}\text { Animal } \\
\text { no. }\end{array}$} & \multirow[b]{2}{*}{$\begin{array}{l}\text { Trial I } \\
\text { (steers) }\end{array}$} & \multirow[b]{2}{*}{$\begin{array}{l}\text { Trial } 2 \\
\text { (sheep) }\end{array}$} & \multicolumn{3}{|c|}{ Trial 3 (sheep) } \\
\hline & & & & $\begin{array}{c}\text { Grab } \\
\text { samples } \\
(M) \dagger\end{array}$ & $\begin{array}{c}\text { Grab } \\
\text { samples } \\
(E) \dagger\end{array}$ & $\begin{array}{c}\text { Combined } \\
\text { grab sample } \\
(M+E) \dagger\end{array}$ \\
\hline & & & Means & & & \\
\hline Capsules & $\begin{array}{l}1 \\
2 \\
3\end{array}$ & $\begin{array}{l}-3.4 \\
-8.0 \\
-2.9\end{array}$ & $\begin{array}{l}-15.8 \pm \\
-10.9 \pm \\
-24.7^{*}\end{array}$ & $\begin{array}{l}-50 \cdot 1^{* *} \\
-58 \cdot 0^{* * *} \\
-90 \cdot 2^{* * *}\end{array}$ & $\begin{array}{l}+18.3 \\
+34.5^{* * *} \\
+30.4^{* * *}\end{array}$ & $\begin{array}{l}-3 \cdot 8 \\
+7 \cdot 8 * \\
-3.3\end{array}$ \\
\hline & Mean & $-4 \cdot 8$ & $-17 \cdot I$ & $-66 \cdot I$ & $+27 \cdot 7$ & +0.2 \\
\hline Paper & $\begin{array}{l}4 \\
5 \\
6\end{array}$ & $\begin{array}{l}-1.1 \\
-1.6 \\
-0.6\end{array}$ & $\begin{array}{l}+5.17 \\
-2.9 \\
+0.4\end{array}$ & $\begin{array}{r}-4.1 \\
+13.4 \pm \\
+7.17\end{array}$ & $\begin{array}{l}-58.07 \\
-29 \cdot 1 * * * \\
-28.7 \ddagger\end{array}$ & $\begin{array}{l}-22 \cdot 9^{*} \\
-3 \cdot 4 \\
-7 \cdot 6\end{array}$ \\
\hline & Mean & $-I \cdot I$ & +0.9 & $+5 \cdot 5$ & $-38 \cdot 6$ & $-11 \cdot 3$ \\
\hline \multicolumn{7}{|c|}{ Standard deviations } \\
\hline Capsules & $\begin{array}{l}1 \\
2 \\
3\end{array}$ & $\begin{array}{l} \pm 3.3 \\
\pm 7.8 \\
\pm 6.5\end{array}$ & $\begin{array}{l} \pm 13.9 \\
\pm 10 \cdot 1 \\
\pm 15 \cdot 0\end{array}$ & $\begin{array}{l} \pm 20 \cdot 2 \\
\pm 17.5 \\
\pm 32.0\end{array}$ & $\begin{array}{r} \pm 26.4 \\
\pm 6.4 \\
\pm 8.3\end{array}$ & $\begin{array}{r} \pm 22.8 \\
\pm 6.0 \\
\pm 13.7\end{array}$ \\
\hline & Mean & \pm 6.2 & \pm 13.2 & $\pm 24^{\cdot I}$ & \pm 16.4 & $\pm 15 \cdot 8$ \\
\hline Paper & $\begin{array}{l}4 \\
5 \\
6\end{array}$ & $\begin{array}{r} \pm 5.9 \\
\pm 5.0 \\
\pm 12.6\end{array}$ & $\begin{array}{r} \pm 4.4 \\
\pm 10.1 \\
\pm 5.2\end{array}$ & $\begin{array}{r} \pm 18 \cdot 4 \\
\pm 11.0 \\
\pm 7.2\end{array}$ & $\begin{array}{r} \pm 52.8 \\
\pm 7.5 \\
\pm 24.5\end{array}$ & $\begin{array}{r} \pm 11 \cdot 5 \\
\pm 7 \cdot 1 \\
\pm 13 \cdot 2\end{array}$ \\
\hline & Mean & $\pm 8 \cdot 5$ & $\pm 7 \cdot 0$ & $\pm 13^{\prime} I$ & \pm 33.9 & \pm 10.9 \\
\hline
\end{tabular}

For details of dosing with $\mathrm{Cr}_{2} \mathrm{O}_{8}$ see p. 212 .

$\dagger M$, grab samples taken in the morning; $E$, grab samples taken in the evening.

$\pm P<0.1$. * $P<0.05$. ** $P<0.01$ *** $P<0.001$.

concentration of $\mathrm{Cr}_{2} \mathrm{O}_{3}$ in grab samples taken at morning dosing $\left(F-D / C_{G M}\right)$ since the main advantages of dosing once daily, a low labour requirement and little interference with the grazing animal, are lost if it is necessary to sample more frequently or at times other than when the dose is administered. The mean standard deviation of the difference $\left(F-D / C_{G M}\right)$ for the sheep receiving capsules once daily, $\pm 24.1 \%$, was much higher than the corresponding value of $\pm 13.2 \%$ obtained with sheep receiving capsules twice daily.

In trial $2, \mathrm{Cr}_{2} \mathrm{O}_{3}$ paper gave better results than capsules; variability was lower and biases were relatively small. The same is true of trial 3 if only the estimates from morning grab samples are considered, but it does not appear that a regime of dosing and sampling once daily would yield results having the accuracy and precision that 
would generally be required. That the different types of dose gave different results with sheep but not in trial I with cattle is probably a reflection not of a species difference but of differences in the feeding patterns. $\mathrm{Cr}_{2} \mathrm{O}_{3}$ is excreted more evenly in faeces when it is given in paper rather than in capsules, primarily because it has become more thoroughly mixed with digesta in, and passing from, the reticulorumen (Corbett et al. 1958). The observations of Balch et al. (1957) suggest that this difference between the two types of dose may be less marked when a large quantity of feed is consumed immediately after dosing, as happened in trial $\mathrm{I}$ in which the six steers were given $40 \mathrm{lb}$ hay immediately after the evening dose, a quantity that would have provided about half of their daily dry-matter intake.

It should be noted that the standard deviations of the total errors in Table 3 are considerably less than might be expected from the standard deviations of the two separate components given in Tables I and 2. This difference is due to the two components being negatively correlated with each other on a within-animal basis. The reason for this correlation $(r=-0.3$ approximately) is obscure, but it presumably indicates that the hour-to-hour pattern of $\mathrm{Cr}_{2} \mathrm{O}_{3}$ excretion is not stable, but changes from day to day in concert with day-to-day changes in faeces output.

The results have been examined for errors in estimates of faeces output, $F$, but Raymond \& Minson (1955) have suggested that, when the ultimate object is to determine the herbage intake of grazing animals, the estimates of faeces output obtained from the concentration of $\mathrm{Cr}_{2} \mathrm{O}_{3}$ in a representative sample $\left(D / C_{R}\right)$ may be more valid because they will be less affected than values of $F$ by variations in the rate of passage of feed through the alimentary tract. In this instance the values for the short-term error given in Table 2 may be more relevant than those for the total error given in Table 3 .

When grab sampling is employed in trials with grazing animals it seems that with $\mathrm{Cr}_{2} \mathrm{O}_{3}$ given by capsule or in paper it would be advisable to determine the mean bias of estimates of faeces output by harnessing some animals for the total collection of faeces. Under such a system for correcting bias the advantages of paper over capsules for controlling random error would remain unimpaired.

\section{SUMMARY}

I. In each of three trials, six steers or six sheep grazed one area of pasture continuously and wore harness for the total collection of faeces. All animals were dosed once or twice daily with standard quantities of chromium sesquioxide $\left(\mathrm{Cr}_{2} \mathrm{O}_{3}\right)$, three animals in each trial receiving finely divided $\mathrm{Cr}_{2} \mathrm{O}_{3}$ in gelatin capsules and three the $\mathrm{Cr}_{2} \mathrm{O}_{3}$ as a component of a specially prepared paper.

2. Measured faecal output, $F$, was compared with the output estimated from the ratio of the $\mathrm{Cr}_{2} \mathrm{O}_{3}$ dose to the concentration in representative samples of the faeces $\left(D / C_{R}\right)$ and to the concentration in grab samples of faeces taken manually from the rectum at one or two fixed times of day $\left(D / C_{G}\right)$. The total error of estimates from grab samples $\left(F-D / C_{G}\right)$ was considered to have two main components, a long-term error expressed as $\left(F-D / C_{R}\right)$ and a short-term error expressed as $\left(D / C_{R}-D / C_{G}\right)$; 
for each component the mean values estimated the bias, and the standard deviations the random component, of these errors.

3. It was concluded that the errors of estimates of faecal output were more stable when $\mathrm{Cr}_{2} \mathrm{O}_{3}$ was administered in paper instead of in capsules. With capsule doses the estimates were liable to include large biases and be subject to large random errors, especially under conditions in which the pattern of feed intake tended to be irregular. Estimates of faecal output obtained from a regime of dosing once daily and grab sampling at the same time of day were unsatisfactory with both types of dose.

We thank Miss S. Gavin and Mr E. Florence for the chemical analyses. One of us (J.P.L.) was in receipt of a postgraduate scholarship from the Ministry of Agriculture, Fisheries and Food.

\section{REFERENCES}

Balch, C. C., Reid, J. T. \& Stroud, J. W. (1957). Brit. F. Nutr. II, I84.

Christian, K. R. \& Coup, M. R. (1954). N.Z. F. Sci. Tech. A, 36, 328.

Commonwealth Bureau of Pastures and Field Crops (196r). Bull. Bur. Past., Hurley, no. 45.

Coop, I. E. \& Hill, M. K. (1962). F. agric. Sci. 58, 187.

Corbett, J. L., Greenhalgh, J. F. D. \& McDonald, A. P. (1958). Nature, Lond., 182, 1014.

Corbett, J. L., Greenhalgh, J. F. D., McDonald, I. \& Florence, E. (1960). Brit. F. Nutr. 14, 289.

Coup, M. R. (1950). Proc. N.Z. Soc. Anim. Prod. ro, 43.

Edin, H., Kihlén, G. \& Nordfeldt, S. (1944-5). LantbrHögsk. Ann. 12, т66.

Kane, E. A., Jacobson, W. C. \& Moore, L. A. (1952). F. Nutr. 47, 263.

Lambourne, L. J. (1957). F. agric. Sci. 48, 273.

Lancaster, R. J., Coup, M. R. \& Percival, J. C. (1953). N.Z. F. Sci. Tech. A, 35, I77.

Langlands, J.P. (r962). Energy intake and its utilisation for maintenance by the intensively grazed ruminant. Ph.D. Thesis, University of Aberdeen.

Raymond, W. F. \& Minson, D. J. (1955). F. Brit. Grassl. Soc. ro, 282.

Smith, A. M. \& Reid, J. T. (I955). F. Dairy Sci. 38, 515.

Wallace, L. R. (1956). Proc. int. Grassl. Congr. vir. Palmerston North, New Zealand, p. I34. 